\title{
PEMETAAN SEBARAN TERUMBU KARANG DI PERAIRAN PULAU KELAPAN, KABUPATEN BANGKA SELATAN BERDASARKAN DATA SATELIT SENTINEL 2A
}

\section{MAPPING THE DISTRIBUTION OF CORAL REEFS IN KELAPAN ISLAND WATERS, SOUTH BANGKA REGENCY BASED ON SENTINEL 2A SATELLITE DATA}

\author{
Khoirul Amrillah, Wahyu Adi* dan Kurniawan \\ Program Studi Manajemen Sumberdaya Perairan, Universitas Bangka Belitung, \\ Kampus Terpadu UBB, Gedung Teladan, Desa Balunijuk, Kepulauan Bangka Belitung, 33172 Indonesia \\ Email korespondensi : emailwahyuadi@gmail.com
}

\begin{abstract}
ABSTRAK
Penelitian ini bertujuan untuk analisis kemampuan data citra satelit Sentinel $2 \mathrm{~A}$ dengan teknologi pengolahan citra untuk pemetaan sebaran terumbu karang di Perairan Pulau Kelapan, menganalisis luasan terumbu karang di perairan dangkal Pulau Kelapan, dan menganalisis kondisi terumbu karang (persentase tutupan, indeks mortalitas, dan keragaman genus) berdasarkan analisa data penyelaman dilapangan. Waktu dan tempat penelitian dilakukan pada bulan Oktober 2018 bertempat di Perairan Pulau Kelapan, Kabupaten Bangka Selatan. Metode penelitian yang digunakan adalah pengolahan citra digital, ground check berdasarkan data pengolahan citra digital, pengambilan data terumbu karang, dan pengukuran parameter lingkungan. Analisis data yang dilakukan yaitu persentase tutupan dan indeks mortalitas. Hasil menunjukkan peta sebaran terumbu karang di Pulau Kelapan, Kabupaten Bangka Selatan berdasarkan data Citra Satelit Sentinel 2 A memiliki 4 kelas yaitu terumbu karang, alga, pasir dan pasir bercampur alga yang memiliki luasan $16.5 \mathrm{Ha}$ atau $12.2 \%$. Kondisi terumbu karang pada stasiun 1 dan 2 masuk kategori sangat baik dengan persentase tutupan sebesar 75.54 dan $78.88 \%$, stasiun 3 kategori sedang dengan persentase sebesar $49.94 \%$, dan pada stasiun 4 termasuk kategori baik dengan persentase $63.74 \%$. Indeks Mortalitas berkisar antara $0.012-0.486$. Jumlah keragaman jenis genus yang ditemukan saat penelitian dilapangan berjumlah 19 jenis genus.
\end{abstract}

Kata kunci: Pulau Kelapan, Satelit Sentinel-2A, Terumbu karang

\section{ABSTRACT}

The purpose of this study was to analyze a map of the distribution of coral reefs based on satellite image data of Sentinel $2 A$, analysis the extent of the coral reefs in shallow waters of Kelapan Island, and analysis of coral reefs condition (percentage cover, mortality index, and genus diversity) based on the diving data analysis. This time and place of research carried out in October 2018 took place on Kelapan Island waters, South Bangka Regency. The research method used digital image processing, ground check based on digital image maps, coral reef data retrieval, and measurement of environmental parameters.

The data analysis was performed, namely the percentage of cover and mortality index. The results show a map of the distribution of coral reefs in Kelapan Island, South Bangka Regency based on Sentinel $2 \mathrm{~A}$ Satellite Image data which has 4 classes, coral reefs, algae, sand and algae mixed sand which have an area of $16.5 \mathrm{Ha}$ or $12.2 \%$ area. The condition of coral reefs at stations 1 and 2 in a very good category with cover of 75.54 and $78.88 \%$ covers, station 3 in the medium category with $49.94 \%$, and at station 4 including a good category with $63.74 \%$. The Mortality Index ranges from $0.012-0.486$. The genus diversity found 19 genuses.

Keywords: Coral Reef, Kelapan Island, Sentinel-2A satellite

\section{PENDAHULUAN}

Kabupaten Bangka Selatan merupakan salah satu Kabupaten yang ada di Provinsi Kepulauan Bangka Belitung dan memiliki luas wilayah kurang lebih 3.607,08 Km2. Berdasarkan letak geografisnya, sebagian besar wilayah Kabupaten Bangka Selatan terletak di Pulau Bangka dan mencakup 59 pulau lainnya, salah satu yakni Pulau Kelapan yang terletak di Kecamatan Lepar Pongok, Kabupaten Bangka Selatan (Badan Pusat Statistik Kabupaten Bangka Selatan, 2017). Pulau Kelapan memiliki sumberdaya alam yang berpotensi terdiri dari ekosistem pesisir dan laut serta keanekaragaman 
hayati seperti ekosistem mangrove, vegetasi lamun, keanekaragaman jenis ikan dan ekosistem terumbu karang. Berdasarkan data Dinas Kelautan Perikanan Provinsi. Bangka Belitung (2004), Ekosistem terumbu karang membentuk terumbu karang tepi disekitar perairan yang mengelilingi pulau dengan dikelilingi ekosistem mangrove dari jenis Rhizopora sp dan Avicennia sp serta vegetasi padang lamun yang dapat ditemukan di sekitar perairan dangkal.

Informasi yang akurat dan terkini mengenai keberadaan sumber daya seperti terumbu karang di wilayah pesisir masih sangat kurang dan sangat diperlukan, karena wilayahnya tersebar luas serta sebagian besar sulit dijangkau. Pendataan terumbu karang membutuhkan teknologi yang mampu memberikan informasi tentang terumbu karang secara efektif dan efisien serta relatif akurat dan menyeluruh. Salah satu informasi yang sangat dibutuhkan adalah peta yang dapat menginformasikan keberadaan, sebaran dan potensi habitat perairan laut dangkal, oleh karena itu untuk mendukung dalam pengelolaan wilayah pesisir tersebut penginderaan jauh diharapkan menjadi teknologi yang mampu menjawab tantangan tersebut. Penginderaan jauh dapat merekam permukaan bumi pada wilayah yang luas serta sulit dijangkau atau daerah yang terisolir. Selain itu, penginderaan jauh juga didukung oleh teknologi menyediakan data citra terbaru dengan waktu perekaman yang berbeda secara up to date, sehingga memiliki resolusi temporal yang baik serta didukung dengan teknologi yang mutakhir sehingga pengembangannya selalu mengikuti perkembangan dari waktu ke waktu (Lillesand dan Kiefer, 1979).

Pemanfaatan teknologi penginderaan jauh untuk melakukan metode analisa geospasial, penyediaan informasi ekosistem terumbu karang terbukti memiliki keunggulan efektifitas biaya. Teknologi dan metode analisa data penginderaan jauh untuk kajian pemetaan ekosistem terumbu karang digunakan sebagai salah satu pendekatan dalam menyediakan informasi geospasial akurat yang dimanfaatkan untuk berbagai kebutuhan. Penggunaan informasi geospasial ekosistem terumbu karang didominasi untuk kebutuhan monitoring, perencanaan serta pengelolaan kawasan. Kebutuhan perencanaan atau pengelolaan kawasan akan berbeda di tiap segmen peruntukannya yang pada akhirnya akan membedakan tingkat keakuratan informasi geospasial yang disediakan (Pusfatja, 2015).

Penelitian ini bertujuan untuk analisis kemampuan data citra satelit Sentinel 2A dengan metode pengolahan citra untuk membuat peta sebaran terumbu karang di Perairan Pulau Kelapan, menganalisis luasan terumbu karang di perairan dangkal Pulau Kelapan, dan menganalisis kondisi terumbu karang (persentase tutupan, indeks mortalitas, dan keragaman genus) berdasarkan analisa data penyelaman dilapangan.

\section{METODE PENELITIAN}

Penelitian dilaksanakan pada bulan Oktober 2018 di Pulau Kelapan, Kabupaten Bangka Selatan. Penentuan stasiun dilakukan berdasarkan hasil setelah pengolahan citra di Pulau Kelapan, Kabupaten Bangka Selatan. Alat dan bahan yang digunakan meliputi alat tulis, kamera digital, alat selam, roll meter, thermometer, $\mathrm{pH}$ meter, secchi disk, Refraktometer, bola arus, data citra satelit Sentinel 2A, dan Laptop. Metode yang digunakan adalah pengolahan citra dengan metode Transformasi lyzenga dan metode survei.

\section{Pengolahan Citra Digital}

Penajaman citra (enhancement) dalam pengertiannya adalah proses mengubah nilai piksel secara sistematis sehingga menghasilkan efek kenampakan citra yang lebih ekspresif sesuai dengan kebutuhan pengguna. Meliputi semua operasi yang menghasilkan citra baru dengan kenampakan visual dan karakteristik spektral yang berbeda. Penajaman Kontras ini bertujuan untuk memperoleh kesan kontras yang lebih tinggi. Dengan mentransformasi seluruh nilai kecerahan maka hasilnya adalah berupa citra baru dengan nilai maksimum awal, dan nilai minimum baru lebih rendah dari nilai minimum awal dan jika dilihat secara visual hasilnya berupa citra baru yang variasi hitam putihnya lebih menonjol sehingga tampak lebih tajam dan memudahkan proses interpretasi (Guntara, 2015).

Komposit warna citra Red Green Blue (RGB) merupakan proses penggabungan 3 saluran band yang berbeda untuk mendapatkan visualisasi citra yang jelas kenampakannya pada objek yang akan kita amati. Pemetaan terumbu karang menggunakan komposit warna Red Green Blue yang digunakan yaitu band 4,3, dan 2 
untuk sentinel 2A. Saluran band yang digunakan memiliki panjang gelombang antara 0,49 - 0,66 $\mu \mathrm{m}$ termasuk cahaya tampak dan baik untuk pemetaan pada perairan laut dangkal (Brando et al. 2016).

Klasifikasi Unsupervised merupakan klasifikasi tidak terbimbing karena belum memiliki data panduan dari lapangan maka dilakukan dengan mengelompokkan piksel pada citra menjadi beberapa kelas berdasarkan analisa statistik pada sebaran nilai piksel (digital number). Satu langkah yang penting adalah penentuan jumlah kelas dalam analisa statistik sebaran nilai piksel/ digital number. Karena penentuan jumlah kelas ini sangat menentukan kebenaran sesuai keadaan sebenarnya di lapangan. Bila jumlah kelas terlalu kecil akan menghilangkan satu kelas yang mungkin ada (Hartoko, 2010). Selanjutnya dilakukan editing class pemisahan habitat dan pengisian warna berbeda sehingga diperoleh semua habitat yang ingin dianalisa dan telah terklasifikasi. Identifikasi ulang dilakukan dengan membandingkan citra hasil koreksi untuk menghasilkan klasifikasi yang lebih sedikit (penggabungan kelas/ class merging) ketika terdapat 2 kelas atau lebih yang memiliki karakteristik penutupan lahan yang sama ingin digabungkan menjadi 1 nama kelas saja sesuai dengan klasifikasi yang dibutuhkan pada skala hasil. Pada proses interpretasi ulang dibantu secar visual menggunakan citra komposit warna atau data hasil kerja lapangan sebagai dasar penggabungan kelas. Penentuan lokasi ground check berdasarkan hasil klasifikasi (Hartoko, 2012)

Transformasi formula Lyzenga adalah metode yang umumnya digunakan untuk menguatkan respon spektral terumbu karang dan membedakannya dengan substrat dasar perairan yang lain. Transformasi Lyzenga dapat mereduksi pengaruh efek kedalaman, pergerakan dan kekeruhan air, untuk meningkatkan perolehan informasi karakteristik dasar perairan dangkal (Helmi et al. 2011). Algoritma formula lyzenga sebagai berikut (Helmi et al. 2011) :

$$
Y=\ln (B 2)+\frac{K i}{K j} * \ln (B 3)
$$

Keterangan : $a=(\operatorname{var} B 2-\operatorname{var} B 3) /$ (2* covarB2B3); $\mathrm{Ki} / \mathrm{Kj}=\mathrm{a}+\left(\mathrm{a}^{2}+1\right)^{1 / 2}$.

Uji akurasi menggunakan metode confusion matrix (Gambar 2) digunakan untuk menghasilkan nilai kuantifikasi dan penilaian terhadap metode yang relative lebih baik untuk ekstraksi dan pemetaan terumbu karang di daerah kajian (Helmi et al. 2011).

Reklasifikasi citra dilakukan untuk memperbaiki ulang hasil klasifikasi awal yang mungkin mengandung kesalahan. Reklasifikasi pada umumnya dilakukan untuk menghilangkan atau mengurangi bahkan menambahkan apabila terdapat kekeliruan dalam proses interpretasi awal dan reklasifikasi biasanya merujuk pada hasil kegiatan lapangan (ground check). Pada langkah terakhir dapat dianalisa luasan pada masing-masing kelas yang diperoleh.

Perhitungan luasan daerah terumbu karang dilakukan dalam pengolahan citra dengan cara Calculate Statistic terhadap file hasil klasifikasi. Kemudian data luasan akan ditunjukkan pada Area Summary Report pada menu bar view di software Er-Mapper. Maka akan muncul luasan pada setiap kelas dalam satuan Hektar, Kilometer persegi, Acre dan Mil persegi (Malik, 2008). Perhitungan luas daerah terumbu karang menggunakan formula berikut:

$$
L=\Sigma p x \operatorname{rr} 0,01
$$

Keterangan: $L=$ Luas $(\mathrm{Ha}) ; \Sigma p=$ Jumlah piksel; $r=$ Resolusi spasial Sentinel-2A (10m $\mathrm{x} 10 \mathrm{~m}$ ); $0,01=$ Konstanta (nilai konversi dari $\mathrm{m}^{2}$ ke dalam ha)

\section{Ground Check}

Ground check (kerja lapangan) menggunakan metode purposive sampling. Metode purposive sampling dilakukan dengan pengambilan data lapangan yang cermat dengan pertimbangan tertentu berkaitan dengan distribusi sampel, dan keterwakilan lokasi kajian sehingga sampel yang dipilih dapat representatif.

Pengambilan data kondisi terumbu karang adalah menggunakan metode Line Intercept Transect (LIT) dilakukan di 4 (empat) stasiun sesuai dengan arah mata angin, yaitu Utara, Selatan, Timur, dan Barat Panjang garis transek $50 \mathrm{~m}$ (English et al. 1997). Parameter kualitas air (suhu, kecerahan, $\mathrm{pH}$, kedalaman, arus dan salinitas) diukur pada tiap stasiun penelitian.

\section{Analisis Data}

Menghitung persentase penutupan masing-masing genus

$$
(N i)=\frac{l i}{L} \times 100 \%
$$

Keterangan : $\mathrm{Ni}=\%$ penutupan karang hidup ke-I; li = Panjang total suatu jenis genus; $L=$ Panjang total tansek. 
Kriteria penilaian persentase kerusakan karang menurut Keputusan Menteri Negara Lingkungan Hidup Nomor 04 Tahun 2001 : Sangat Baik $=(75 \%-100 \%$; Baik $=50 \%-$ $74,9 \%$; Sedang $=25 \%-49,9 \%$; Buruk $=$ $0 \%-24,9 \%$.

\section{Indeks Mortalitas (IM)}

Indeks mortalitas digunakan untuk mengetahui rasio kematian karang (English, et al , 1997). Indeks ini memperlihatkan besarnya perubahan karang hidup menjadi karang mati. Nilai indeks mortalitas jika mendekati 0,0 maka menunjukkan hampir tidak ada kematian karang, sedangkan jika nilai mendekati 1,0 maka menunjukkan bahwa terjadi perubahan yang berarti dari karang hidup menjadi karang mati (English , et al , 1997)

\section{HASIL DAN PEMBAHASAN}

Peta sebaran terumbu karang dan luasan didapatkan dari pengolahan citra digital menggunakan software $\mathrm{Er}$ - Mapper 7.0 dan Arcgis 10.3. Kondisi terumbu karang didapatkan dengan pengambilan data di lapangan menggunakan metode Line Intercept Transect (LIT).

Daerah pada citra hasil klasifikasi dibagi menjadi enam kelas yaitu terumbu karang, laut, darat, pasir, alga, dan pasir bercampur alga. Pembagian kelas-kelas mengacu pada data lapangan di lokasi penelitian berupa foto bawah air. Pengolahan citra menggunakan klasifikasi terbimbing supervised classification dengan software $\mathrm{Er}$ Mapper 7.0. Peta sebaran terumbu karang di Pulau Kelapan,
Kabupaten Bangka Selatan dengan pengolahan citra hasil klasifikasi disajikan dalam bentuk peta pada Gambar 1. Hasil peta sebaran terumbu karang menunjukkan beberapa kelas diantaranya terumbu karang, alga, pasir, dan pasir bercampur alga. Berdasarkan data Dinas Kelautan dan Perikanan Provinsi Bangka Belitung (2004), Pulau kelapan memiliki ekosistem pesisir seperti mangrove dan terumbu karang yang mengelilingi pulau yang merupakan potensi untuk pengembangan pulau dimasa depan. Peta sebaran terumbu karang di Pulau Kelapan menunjukkan kelas-kelas dengan keterangan terumbu karang berwarna merah muda, alga berwarna coklat muda, pasir berwarna biru muda, dan pasir bercampur alga berwarna merah. Peta disajikan dalam proyeksi Universal Transverse Mercator (UTM) dengan datum untuk kontrol horizontal yang digunakan adalah Datum World Geodetic System 1984 (WGS-84). Penentuan warna dan proyeksi peta mengacu pada Rancangan Standar Nasional Indonesia-3 (RSNI) tentang pemetaan habitat perairan laut dangkal bagian 1 yaitu Pemetaan Terumbu Karang dan Padang Lamun tahun 2011.

Pemetaan sebaran terumbu karang di Pulau Kelapan menggunakan citra satelit Sentinel-2A dengan data perekaman maret 2018. Citra satelit sentinel-2A merupakan citra satelit yang termasuk kategori resolusi tinggi dengan resolusi spasial 10 meter dengan panjang gelombang 0,490 - 0,665 $\mu \mathrm{m}$. Pendeteksian terumbu karang menggunakan citra satelit adalah dengan memanfaatkan nilai reflektansi kemudian direkam oleh sensor (Brando et al., 2016).

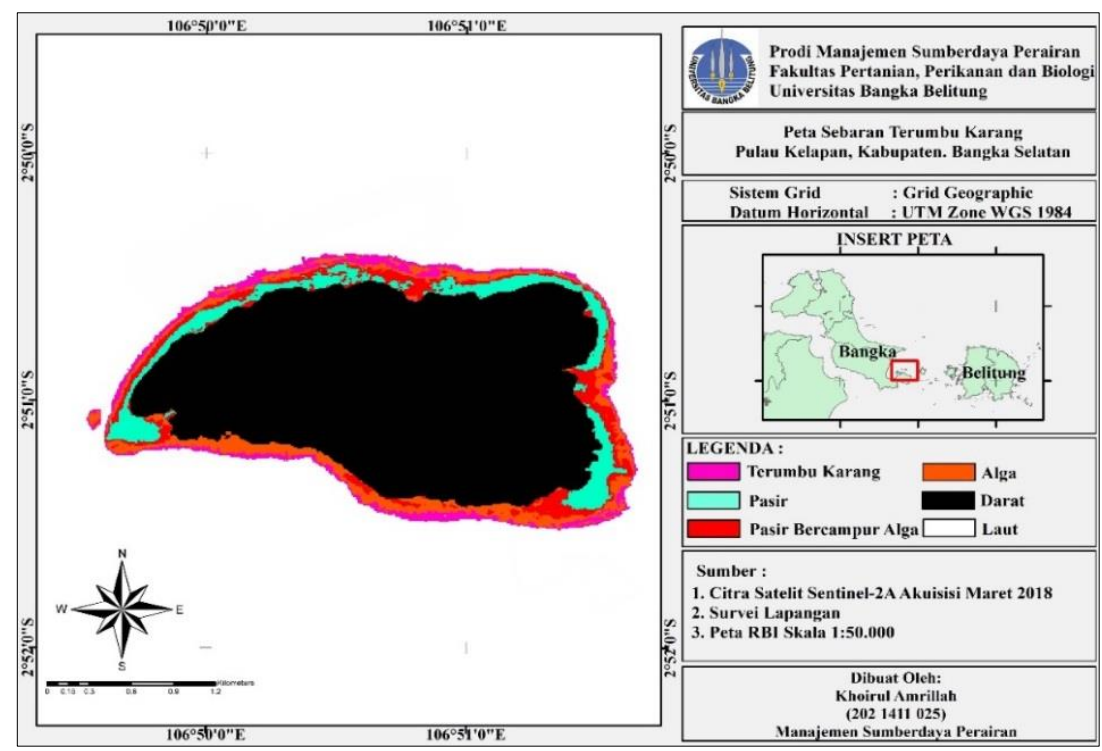

Gambar 1. Peta Sebaran Terumbu Karang di Pulau Kelapan 


\begin{tabular}{|c|c|c|c|c|c|c|c|c|c|}
\hline & Tabel & nfusi Matrix & & & & & & & \\
\hline 10 & Nama & $\mathrm{x}$ & $\mathrm{r}$ & Ket & NO & Nama & $\mathrm{x}$ & $\mathrm{Y}$ & Ket \\
\hline 1 & Karang & $106^{\circ} 51^{\prime} 32.8$ & $2^{2} 50^{\prime} 57.5$ & $v$ & 26 & Pasir & $106^{\circ} 49^{\prime} 47.85$ & $2^{8} 51^{\prime} 12.88$ & $v$ \\
\hline 2 & Pasir & $106^{\circ} 51^{\prime} 35.54$ & $2^{2} 51^{\prime} 3.1$ & $v$ & 27 & $\begin{array}{l}\text { Pasir } \\
\text { bercampur } \\
\text { alga }\end{array}$ & $106^{\circ} 49^{\prime} 50.59$ & $2^{2} 51^{1} 12.55$ & $v$ \\
\hline 3 & Karang & $106^{\circ} 51^{\prime} 36.73$ & $2^{2} 51^{\prime} 7.31$ & $v$ & 28 & Karang & $106^{\circ} 49^{\prime} 52.36$ & $2^{2} 51^{\prime} 12.55$ & $v$ \\
\hline 4 & Pasir & $106^{\circ} 51^{\prime} 39.36$ & $2^{2} 51^{\prime} 1.62$ & $v$ & 29 & Karang & $106^{\circ} 49^{\prime} 53.59$ & $2^{\circ} 51^{\prime} 12.76$ & $\mathrm{x}$ \\
\hline 5 & Karang & $106^{\circ} 51^{\prime} 35.26$ & $2^{8} 50^{\prime} 52.91$ & $v$ & 30 & Karang & $106^{\circ} 49^{\prime} 56.22$ & $2^{2} 51^{\prime} 12.65$ & $\mathrm{x}$ \\
\hline 6 & Karang & $106^{\circ} 51^{\prime} 34.93$ & $2^{2} 50^{\prime} 51.73$ & $v$ & 31 & Alga & $106^{\circ} 49^{\prime} 57.83$ & $2^{2} 51^{\prime} 12.91$ & $v$ \\
\hline 7 & Alga & $106^{\circ} 51^{\prime} 34.71$ & $2^{\circ} 50^{\prime} 47.2$ & v & 32 & Pasir & $106^{\circ} 50^{\prime} 22.4$ & $2^{\circ} 51^{\prime} 15.09$ & $v$ \\
\hline 8 & Pasir & $106^{\circ} 51^{\prime} 34.6$ & $2^{2} 50^{\prime} 45.74$ & $v$ & 33 & $\begin{array}{l}\text { Karang } \\
\text { Pasir } \\
\text { bercampur }\end{array}$ & $106^{\circ} 50^{\prime} 25.73$ & $2^{\circ} 51^{\prime} 16.38$ & $v$ \\
\hline 9 & Karang & $106^{\circ} 51^{\prime} 34.28$ & $2^{2} 50^{\prime} 44.77$ & $v$ & 34 & alga & $106^{\circ} 50^{\prime} 37.71$ & $2^{2} 51^{\prime} 26.44$ & $v$ \\
\hline 10 & Karang & $106^{\circ} 51^{\prime} 33.52$ & $2^{2} 50^{\prime} 38.84$ & $\mathrm{x}$ & 35 & Alga & $106^{\circ} 50^{\prime} 43.23$ & $2^{2} 51^{\prime} 28.21$ & $v$ \\
\hline 11 & Alga & $106^{\circ} 51^{\prime} 33.68$ & $2^{2} 50^{\prime} 37.22$ & $v$ & 36 & Pasir & $106^{\circ} 50^{\prime} 55.46$ & $2^{2} 51^{\prime} 28.46$ & $\mathrm{x}$ \\
\hline 12 & Pasir & $106^{\circ} 51^{\prime} 29.38$ & $2^{\circ} 50^{\prime} 32.59$ & v & 37 & Karang & $106^{\circ} 50^{\prime} 58.25$ & $2^{2} 51^{\prime} 28.24$ & $\mathrm{x}$ \\
\hline 13 & Karang & $106^{\circ} 51^{\prime} 28.04$ & $2^{2} 50^{\prime} 31.62$ & $v$ & 38 & Karang & $106^{\circ} 51^{\prime} 37.86$ & $2^{\circ} 51^{\prime} 10.06$ & $v$ \\
\hline 14 & Karang & $106^{\circ} 51^{\prime} 22.56$ & $2^{2} 50^{\prime} 28.34$ & $v$ & 39 & $\begin{array}{l}\text { Pasir } \\
\text { bercampur } \\
\text { alga }\end{array}$ & $106^{\circ} 51^{\prime} 37.11$ & $2^{2} 51^{\prime} 9.09$ & $\mathrm{x}$ \\
\hline 15 & Alga & $106^{\circ} 51^{\prime} 20.84$ & $2^{2} 50^{\prime} 27.8$ & $v$ & 40 & $\begin{array}{l}\text { Pasir } \\
\text { bercampur } \\
\text { alga }\end{array}$ & $106^{\circ} 51^{\prime} 37.59$ & $2^{2} 51^{\prime} 8.28$ & $\mathrm{v}$ \\
\hline 16 & Pasir & $106^{\circ} 51^{\prime} 31.26$ & $2^{2} 50^{\prime} 33.99$ & $v$ & 41 & Pasir & $106^{\circ} 51^{\prime} 36.24$ & $2^{2} 51^{\prime} 6.23$ & $v$ \\
\hline 17 & Karang & $106^{\circ} 51^{\prime} 34.44$ & $2^{2} 50^{\prime} 46.82$ & $\mathrm{x}$ & 42 & Alga & $105^{\circ} 51^{\prime} 35.28$ & $2^{2} 51^{4} 5.26$ & $\mathrm{x}$ \\
\hline 18 & Alga & $106^{\circ} 50^{\prime} 21.04$ & $2^{2} 50^{\prime} 28.55$ & $v$ & 43 & Alga & $106^{\circ} 51^{\prime} 35.59$ & $2^{2} 51^{\prime} 2.73$ & $v$ \\
\hline 19 & Alga & $106^{\circ} 50^{\prime} 8.8$ & $2^{2} 50^{\prime} 32.07$ & $v$ & 44 & Daratan & $106^{\circ} 51^{\prime} 35.1$ & $2^{\circ} 50^{\prime} 55.12$ & $v$ \\
\hline 20 & Pasir & $106^{\circ} 50^{\prime} 2$. & $2^{2} 50^{\prime} 3$ & $v$ & 45 & Dermaga & $106^{\circ} 51^{\prime} 36.46$ & $2^{2} 51^{\prime} 4.99$ & $v$ \\
\hline 21 & Laut & $106^{\circ} 49^{\prime} 45.13$ & $2^{2} 50^{\prime} 47.91$ & $v$ & 46 & $\begin{array}{l}\text { Pasir } \\
\text { Pasir } \\
\text { bercampur }\end{array}$ & $106^{\circ} 51^{\prime} 35.09$ & $2^{\circ} 50^{\prime} 49.24$ & v \\
\hline 22 & $\begin{array}{l}\text { Karang } \\
\text { Pasir } \\
\text { bercampur }\end{array}$ & $106^{\circ} 49^{\prime} 91.55$ & $2^{2} 50^{\prime} 52.5$ & $v$ & 47 & alga & $106^{\circ} 51^{\prime} 34.0$ & $2^{2} 50^{\prime} 49.41$ & $v$ \\
\hline 23 & Alga & & $2^{2} 51^{\prime} 5$ & $v$ & 48 & & & $2^{\circ} 50^{\prime} 43.53$ & $v$ \\
\hline 26 & Pasir & $106^{\circ} 49^{\prime} 41.74$ & $2^{2} 51^{\prime} 14.02$ & $x$ & 49 & Karang & $106^{\circ} 51^{\prime} 34.7$ & $2^{2} 50^{\prime} 40.02$ & $v$ \\
\hline 25 & Karang & $106^{\circ} 49^{\prime} 46.3$ & $2^{2} 51^{\prime} 12.5$ & $v$ & 50 & Laut & $106^{\circ} 51^{\prime} 32.71$ & $2^{\circ} 50^{\prime} 35.93$ & $\mathrm{v}$ \\
\hline
\end{tabular}

Gambar 2. Hasil Tabel Konfusi Matrix dan Uji Akurasi

Hasil uji akurasi hasil citra digital dengan pengecekan dilapangan menunjukkan nilai akurasi 84\%. Menurut Prawoto (2016) dalam penelitiannya mendapatkan hasil dari uji akurasi citra sentinel-2A dengan menggunakan koreksi kolom air lyzenga secara keseluruhan adalah sebesar $80,73 \%$. Nilai tersebut menunjukkan besar nilai kesesuaian hasil klasifikasi dengan kondisi di lapangan. Dari hasil uji akurasi yang telah dilakukan, dapat dikatakan bahwa dengan penggunaan koreksi kolom air lyzenga maka dapat meningkatkan akurasi citra dalam pemetaan habitat bentik.

Menurut Damayanti (2012), ada beberapa literatur yang menyebutkan uji akurasi bisa dikatakan mewakili apabila nilainya minimal $80 \%$. Merujuk dari hal ini uji akurasi yang didapatkan bisa dikatakan juga cukup memadai walaupun hanya menggunakan citra satelit Landsat 8 . Selain itu hasil interpretasi terumbu karang memiliki nilai kebenaran 7 banding 8 , artinya informasi tutupan terumbu karang yang diberikan oleh citra Landsat menggunakan algoritma Lyzenga cukup mewakili keadaan di lapangan. Salah satu hal yang penting dalam kegiatan penelitian dan pengembangan adalah validasi dan uji akurasi karena dengan melakukan tahapan tersebut, keberhasilan sebuah litbang akan terukur. Uji akurasi diperlukan data lapangan yang akurat agar uji akurasi dan validasi dianggap benar. Data lapangan ada dua hal yaitu posisi geografis dan jenis tutupan lahannya sesuai kategori pengkelasan yang digunakan (Winarso, et al, 2015).

\section{Luasan Sebaran Terumbu Karang}

Hasil klasifikasi citra menggunakan Algoritma Lyzenga dikelompokkan menjadi 4 kelas yang mewakili substrat dasar perairan, yakni kelas terumbu karang, pasir, alga, dan pasir bercampur alga. Setelah melakukan 
transformasi Algoritma Lyzenga dan mengkelaskan substrat dasar dengan teknik klasifikasi tidak terbimbing (Unsupervised classification) pada hasil citra satelit, maka luasan terumbu karang dapat dihitung secara sistematis oleh software Er-Mapper 7.0 berdasarkan hasil klasifikasi. Luasan masing-masing kelas tutupan (Tabel 1).

Hasil klasifikasi dengan metode klasifikasi terbimbing seperti terdapat pada tabel didapatkan hasil luasan tiap-tiap kelas yang didapat dalam pengolahan citra hasil klasifikasi terbesar berturut-turut adalah pasir ukuran luasan $47,0 \mathrm{Ha}$, pasir bercampur alga seluas 36,4 $\mathrm{Ha}$, Alga seluas $35,3 \mathrm{Ha}$, dan terumbu karang dengan luasan $16,5 \mathrm{Ha}$. Luasan dari tiap-tiap kelas disajikan dalam bentuk Tabel 4 .

Hasil pemetaan menunjukkan keberadaan alga cukup mendominasi pada lokasi penelitian dari pada terumbu karang. Neviaty (2015) menjelaskan bahwa Alga merupakan salah satu pesaing terumbu karang dalam mendapatkan ruang untuk bertahan hidup. Pertumbuhan terumbu karang akan terganggu dengan banyaknya alga dalam suatu perairan. Semakin banyak alga, maka dominasi terumbu karang semakin berkurang.

Menurut Siregar, et al (2017) alga dapat bersaing dengan karang menutupi dan menghalangi cahaya matahari yang menyediakan $90 \%$ lebih makanan bagi karang. Secara umum faktor yang mempengaruhi keberadaan alga diantaranya yaitu, substrat keras dan kokoh yang berfungsi sebagai tempat melekat, substart berpasir, dan karang mati, perairan yang cukup untuk mendapatkan cahaya, nutrient yang diperlukan diperoleh dari nutrient tersuspensi pada air laut, faktor lingkungan setempat, pemangsa dan kompetisi. Alga sebenarnya bukanlah ancaman bagi kelangsungan hidup karang karena alga juga berfungsi sebagai produsen primer yaitu sumber makanan utama bagi ikan herbivora, penambah daya dukung ekosistem terumbu karang. Namun, pertumbuhan alga yang begitu cepat berdampak negatif terhadap terumbu karang yang umumnya tumbuh dengan lambat.
Dwimasayanti (2018) menambahkan bahwa alga memiliki kemampuan dalam bertahan hidup pada lingkungan yang memiliki arus kuat. Alga memiliki sistem perakaran yang terbenam dalam pasir, menempel pada batu atau sela-sela karang dan memiliki thalus yang mengalami kalsifikasi sehingga menjadikan spesies tersebut mampu berkembang pada kondisi arus yang kuat. Hal ini juga didukung dengan kondisi arus pada saat penelitian dilapangan didapatkan hasil arus rata-rata $0,026 \mathrm{~m} / \mathrm{s}$ dan memiliki kecerahan perairan yang rata-rata $100 \%$. Luthfi dan Anugrah (2017) menambahkan walaupun kondisi ekosistem terumbu karang dalam kategori baik, tutupan pasir dan Dead Coral Algae yang tinggi di beberapa tempat mengindikasikan perlu adanya usaha pengelolaan yang lebih intensif, guna menjaga kelestarian ekosistem terumbu karang yang ada.

\section{Kondisi Ekosistem Terumbu Karang di Perairan Pulau Kelapan}

Pemetaan dengan menggunakan penginderaan jauh belum dapat mengetahui kondisi terumbu karang di daerah tersebut. Pengamatan lapangan pada daerah penelitian perlu dilakukan untuk memperoleh informasi yang lebih rinci dan akurat mengenai kondisi terumbu karang. Pengamatan kondisi terumbu karang dilakukan dengan metode Line Intercept Transect (LIT) sepanjang 50 meter. Hasil dari penelitian yang telah dilakukan diperoleh 19 genus karang di perairan Pulau Kelapan yaitu: Acropora, Cycloceris, Echinopora, Euphyllia, Favia, Fungia, Galaxea, Hydnophora, Lobophylla, Merulina, Montipora, Pachyseris, Pavona, Pectinia, Platygyra, Pocillopora, Porites, Psammocora, Seriatopora. Keanekaragaman jenis terumbu karang berdasarkan genus karang dan bentuk pertumbuhan terumbu karang disajikan pada Tabel 2, kondisi persentase tutupan terumbu karang tiap stasiun dapat dilihat pada Tabel 3, dan nilai indeks mortalitas disajikan pada Tabel 4.

Tabel 1.Luasan masing-masing kategori dalam peta sebaran terumbu karang di Pulau Kelapan

\begin{tabular}{lccc}
\hline \multicolumn{1}{c}{ Kategori } & Luasan $(\mathrm{Ha})$ & Keterangan $(\%)$ & Keterangan Warna \\
\hline Terumbu Karang & 16.5 & $12.2 \%$ & Merah Muda \\
Alga & 35.3 & $26.1 \%$ & Coklat Muda \\
Pasir & 47.0 & $34.8 \%$ & Biru Muda \\
Pasir Bercampur Alga & 36.4 & $26.9 \%$ & Merah \\
Total & 135.2 & $100 \%$ & \\
\hline
\end{tabular}


Tabel 2. Persentase Tutupan Terumbu Karang Berdasarkan Genus

\begin{tabular}{|c|c|c|c|c|c|}
\hline Kategori & St 1 & St 2 & St 3 & St 4 & Jumlah \\
\hline Acropora & 10.72 & 12.06 & - & 36.32 & 59.10 \\
\hline Cycloceris & 0.10 & - & - & - & 0.10 \\
\hline Echinopora & 6.24 & 7.62 & 0.26 & - & 14.12 \\
\hline Euphyllia & 0.76 & - & - & - & 0.76 \\
\hline Favia & 0.20 & 0.40 & 1.02 & 3.20 & 4.82 \\
\hline Fungia & 0.42 & 0.20 & 0.30 & - & 0.92 \\
\hline Galaxea & 2.92 & 15.56 & - & - & 18.48 \\
\hline Hydnophora & - & 10.88 & 1.26 & - & 12.14 \\
\hline Lobophylla & - & - & 0.38 & - & 0.38 \\
\hline Merulina & 31.22 & - & 31.04 & 8.76 & 71.02 \\
\hline Montipora & 5.92 & 26.32 & 2.46 & 17.60 & 52.30 \\
\hline Pachyseris & 2.74 & - & - & - & 2.74 \\
\hline Pavona & 6.88 & 4.26 & 0.20 & - & 11.34 \\
\hline Pectinia & - & 0.20 & 1.70 & - & 1.90 \\
\hline Platygyra & - & 1.18 & - & 0.42 & 1.60 \\
\hline Pocillopora & - & - & - & 1.80 & 1.80 \\
\hline Porites & 3.28 & - & 11.32 & 5.20 & 19.80 \\
\hline Psammocora & 4.14 & - & - & - & 4.14 \\
\hline Seriatopora & - & 0.20 & - & - & 0.20 \\
\hline Turf algae & - & - & 0.14 & - & 0.14 \\
\hline Dead coral & 0.50 & - & - & 0.80 & 1.30 \\
\hline Dead coral algae & 23.44 & 21.12 & 47.22 & 24.60 & 116.38 \\
\hline Others fauna & 0.52 & - & 2.70 & 1.30 & 4.52 \\
\hline Jumlah \% & 100 & 100 & 100 & 100 & 400 \\
\hline
\end{tabular}

Tabel 3. Persentase tutupan karang hidup tiap stasiun penelitian

\begin{tabular}{lcc}
\hline \multicolumn{1}{c}{ Stasiun } & \% Tutupan Karang Hidup & Kategori \\
\hline Stasiun 1 (Barat) & 75.54 & Sangat baik \\
Stasiun 2 (Timur) & 78.88 & Sangat baik \\
Stasiun 3 (Selatan) & 49.94 & Sedang \\
Stasiun 4 (Utara) & 63.74 & Baik \\
\hline
\end{tabular}

Sumber: Keputusan Menteri Lingkungan Hidup Nomor 4 Tahun 2001

Tabel 4. Nilai Indeks Mortalitas

\begin{tabular}{cc}
\hline Stasiun & Indeks Mortalitas Karang (IMK) \\
\hline Stasiun 1 & 0.241 \\
Stasiun 2 & 0.211 \\
Stasiun 3 & 0.486 \\
Stasiun 4 & 0.012 \\
\hline
\end{tabular}

Hasil penelitian menunjukkan jumlah genus dan bentuk pertumbuhan pada 4 stasiun berjumlah 21 dengan genus tertinggi terdapat pada stasiun 1 dan 3 sebanyak 14 dan 12 genus (Tabel 2). Genus yang mendominasi Merulina, Acropora dan Montipora. Muzaki, et al (2010) menambahkan bahwa perairan Pulau Kelapan memiliki genus terumbu karang yang dominan yaitu Merulina, Pachseris dan 
Montipora. Genus-genus tersebut terutama termasuk kedalam bentuk pertumbuhan coral foliose yang merupakan jenis yang umum dijumpai dan mudah beradaptasi pada kondisi perairan yang keruh dan bersedimentasi. Bentuk karang yang pipih seperti daun dan melebar seperti payung memungkinkan zooxanthellae dapat menyerap maksimal cahaya matahari untuk proses fotosintesis. Bentuknya yang melebar seperti payung juga dapat menyebabkan karang ini lebih mudah berkompetisi dalam mendapatkan cahaya dan makanan jika dibandingkan dengan jenis karang lainnya. Karang-karang jenis sub massive dan massive juga merupakan jenis karang yang mempunyai adaptasi yang tinggi terhadap kondisi perairan yang agak keruh (Muzaki, et $a l, 2010)$.

Secara umum persentase tutupan karang hidup di perairan Pulau Kelapan berkisar antara $49.94 \%$ - 78.88\%, dimana stasiun 2 atau bagian timur pulau memiliki persentase tutupan karang hidup yang lebih tinggi dibandingkan dengan perairan stasiun 3 atau bagian selatan. Terumbu karang pada pada perairan pulau Kelapan tersebut terdapat pada kedalaman antara 3 - 10 meter. Substrat dasar berupa pasir.

Terumbu karang di stasiun 1 termasuk kategori sangat baik yang memiliki persentase tutupan $75.54 \%$. Tingginya tutupan karang di daerah ini diduga karena dekat dengan perairan terbuka, stasiun ini terletak disebelah barat pulau kelapan seperti terlihat pada Gambar 1. Daerah perairan ini relatif tenang karena berada didaerah yang masih terlindung. Pada stasiun 1 jenis terumbu karang yang paling banyak ditemukan adalah genus Merulina sebesar $31,22 \%$, stasiun 1 terdapat 13 spesies yang disajikan dalam tabel 2 .

Kondisi terumbu karang di stasiun 2 termasuk kategori sangat baik dengan persentase tutupan paling tinggi dari stasiun lainnya yaitu $78.88 \%$. Stasiun ini terletak disebelah timur Pulau Kelapan, tingginya tutupan karang diduga karena menghadap pada perairan terbuka menjadikan arus lebih deras dan mengurangi sedimen yang menempel pada terumbu karang. Pada stasiun 2 jenis terumbu karang yang paling banyak ditemukan adalah genus Montipora dengan persentase sebesar $26.32 \%$. Habitat Genus Montipora umumnya hidup pada perairan dengan kedalaman 3-15 meter. Perairan yang dangkal berkaitan dengan intensitas cahaya yang mana sering ditemukan dominasi pada suatu daerah tergantung pada intensitas cahaya (Suharsono, 2008).

Kondisi terumbu karang di stasiun 3 termasuk kategori sedang dan paling rendah dari stasiun lainnya yaitu sebesar $49.94 \%$. Stasiun ini terletak disebelah selatan pulau, rendahnya tutupan karang diduga akibat pengaruh aktifitas dari daratan yang menimbulkan sedimen sebab stasiun ini berhadapan langsung dengan daratan pulau lepar, serta dipengaruhi juga oleh aktifitas manusia yang sering melakukan penangkapan ikan pada daerah tersebut. Pada stasiun 3 jenis terumbu karang yang paling banyak ditemukan adalah genus Merulina dengan persentase sebesar $31.04 \%$. Karang genus Merulina banyak dijumpai hidup pada kedalaman 3-15 meter dan karang ini umumnya banyak hidup diperairan dangkal dan berarus deras (Suharsono,2008).

Kondisi terumbu karang stasiun 4 termasuk kategori baik dengan tutupan karang sebesar $63.74 \%$. Stasiun ini terletak pada bagian utara Pulau Kelapan. Daerah ini menghadap langsung pada perairan terbuka dan Selat Gaspar. Pada stasiun 4 jenis terumbu karang yang paling banyak ditemukan adalah genus Acropora dengan persentase tutupan sebesar $36 \%$. Karang genus Acropora umumnya terdapat hidup di kedalaman laut 3-5 meter, menempel pada batu karang dan biasa ditemukan pada rataan terumbu sampai pada daerah tubir sering mendominasi suatu lokasi tertentu terutama pada perairan jernih dengan ombak yang relative tidak besar (Suharsono,2008)

Pada saat pengamatan semua stasiun banyak ditemukan alga yang tumbuh pada karang yang mati dengan persentase dari tiap-tiap stasiun yaitu stasiun 1 sebesar $23.44 \%$, stasiun 2 sebesar $21.12 \%$, stasiun 3 sebesar $47.22 \%$, dan stasiun 4 sebesar $24.60 \%$, dengan tumbuhnya alga yang begitu cepat bisa menjadi berdampak negatif bagi kelangsungan hidup terumbu karang yang lambat. Semakin banyak alga, maka dominasi terumbu karang semakin berkurang. Sebelum mengalami kematian, terlebih dahulu terumbu karang akan terkena penyakit baik yang berasal dari dari faktor alam maupun lingkungan. Terumbu karang dapat memulihkan diri ketika terserang penyakit, tapi membutuhkan waktu yang lama. Ketika terumbu karang sakit, maka alga akan tumbuh di atas terumbu karang. Ketika alga tersebut telah mendominasi individu terumbu karang, 
maka terumbu karang akan sulit untuk memulihkan diri dari penyakit (Neviaty, 2015).

Setiawan, et al (2017) menambahkan apabila nilai alganya tinggi mengindikasikan banyak substrat yang telah diselimuti alga. Kompetisi ruang antara alga dan karang menunjukan lokasi tersebut kandungan nutriennya tinggi sehingga alga dapat tumbuh subur.

Hasil penelitian pada terumbu karang Pulau Kelapan memiliki tingkat kematian berkisar antara 0.012-0.486. Daerah terumbu karang yang paling rendah tingkat kematiannya terdapat pada stasiun 4 atau bagian utara pulau Kelapan dengan nilai 0.012. Menurut English, et al (1994) nilai indeks mortalitas yang mendekati 0.0 menunjukkan hampir tidak ada kematian karang, sedangkan nilai yang mendekati 1.0 menunjukkan bahwa terjadi perubahan yang berarti dari karang hidup menjadi karang mati.

Marsadin, et al (2011) menambahkan secara umum nilai Indeks Mortalitas diseluruh stasiun pengamatan masih menunjukkan bahwa pada lokasi penelitian memiliki kondisi lingkungan yang mendukung bagi kehidupan karang sehingga rasio kematian karang relatif rendah, dan hal ini juga didukung dengan nilai kriteria baku kerusakan terumbu karang yang tergolong baik menurut Kep. MENLH No 4 Tahun 2001.

Stasiun paling tinggi tingkat kematiannya terdapat pada stasiun 3 dengan nilai 0.486. Menurut Purbani, et al (2014) hal ini menunjukkan bahwa tingkat kematian karang dalam kategori sedang. Walaupun demikian nilai ini cukup mengkhawatirkan karena tingkat tekanan ekologis yang cukup tinggi, dan hal ini bisa mengakibatkan kematian karang terus terjadi. Tekanan ekologis ini dapat berupa tekanan alami dan atau antropologis seperti praktek penangkapan ikan yang tidak ramah lingkungan.

\section{Paremeter Fisika dan Kimia Perairan}

Kualitas perairan yang dimaksud adalah parameter fisika dan kimia yang berhubungan dengan kelangsungan hidup terumbu karang meliputi suhu, kedalaman, kecerahan, arus, pH dan salinitas. Parameter perairan pada tiap stasiun disajikan pada Tabel 5.

Menurut Puspitasari, et al (2016) pertumbuhan terumbu karang dipengaruhi oleh kualitas perairan karena terumbu karang memiliki rentang optimum untuk dapat tumbuh, berkembangbiak dan bertahan hidup. Parameter lingkungan yang digunakan dalam penelitian ini yaitu suhu, kecerahan, arus, pH (derajat keasaman), dan salinitas.

Secara umum kondisi perairan pada saat pengambilan data di Pulau Kelapan masih dalam toleransi pertumbuhan karang untuk tumbuh dengan baik. Suhu perairan tersebut rata-rata $31^{\circ} \mathrm{C}$ dengan kondisi sekitar pada saat pengambilan data yaitu menjelang siang hari, cerah serta tutupan awan sedikit sekali. Suhu pada kisaran ini merupakan suhu yang masih baik bagi pertumbuhan karang. Siregar, et al (2017) yang menyatakan bahwa terumbu karang pada umumnya ditemukan terbatas pada suhu perairan antara $18-36^{\circ} \mathrm{C}$, sedangkan nilai optimal karang pertumbuhan karang berkisar $26-28^{\circ} \mathrm{C}$.

Suhu permukaan air laut menjadi perhatian dikarenakan kenaikan $1^{\circ} \mathrm{C}$ suhu permukaan dari rerata suhu terpanas tahunannya akan membuat karang mengalami pemutihan (bleaching). Suhu permukaan air laut pula memicu meningkatnya jumlah patogen pada koloni karang sehingga berdampak pada munculnya beberapa penyakit karang seperti white syndrome, black band disease dan skeletal eroding band (Wibawa dan Luthfi, 2017).

Berdasarkan hasil pengukuran kecerahan bahwa rata-rata tingkat kecerahan di stasiun penelitian adalah $100 \%$. Artinya, kondisi perairan yang ada cukup jernih sehingga memungkinkan cahaya matahari dapat menembus sampai dasar perairan bila kedalaman perairan tersebut dangkal. Menurut Puspitasari, et al(2016) Kecerahan menunjukkan intensitas cahaya matahari yang dapat menembus lapisan-lapisan air, makin keruh airnya makin kecil intensitas sinar yang dapat masuk ke dalam air.

Kecerahan perairan berhubungan dengan ketersediaan intensitas cahaya matahari yang dapat digunakan oleh zooxanthellae untuk melangsungkan fotosintesis secara optimal sehingga mendukung pertumbuhan karang (Puspitasari, et al, 2016).

Kondisi arus di Perairan Pulau Kelapan berdasarkan hasil yang ditunjukkan Tabel 5 pada kisaran 0.021-0.033 m/detik dengan rata-rata arus $0.026 \mathrm{~m} /$ detik. Secara keseluruhan kondisi kecepatan arus sudah 
Tabel 5. Parameter Fisika dan Kimia Perairan

\begin{tabular}{cccccc}
\hline No & Parameter & Stasiun 1 & Stasiun 2 & Stasiun 3 & Stasiun 4 \\
\hline 1 & Suhu ${ }^{\circ} \mathrm{C}$ & 31 & 31 & 31 & 32 \\
2 & Kecerahan (\%) & 100 & 100 & 100 & 100 \\
3 & Arus (m/s) & 0.021 & 0.026 & 0.025 & 0.033 \\
4 & $\mathrm{pH}$ & 7 & 7 & 7 & 7 \\
5 & Salinitas (ppt) & 32 & 31 & 31 & 32 \\
\hline
\end{tabular}

cukup baik bagi pertumbuhan karang. Rizal, et al (2016) menyebutkan bahwa keberadaan arus dan gelombang di perairan sangat penting bagi kelangsungan hidup terumbu karang. Arus berperan sebagai pengadukan bahan makanan untuk polip karang, membersihkan bagian dari terumbu karang terhadap endapan - endapan serta mensuplai oksigen dari laut bebas. Pertumbuhan karang lebih baik pada wilayah dengan arus kuat dibandingkan pada wilayah dengan arus yang lemah.

Derajat keasaman $(\mathrm{pH})$ di stasiun pengamatan rata-rata memiliki nilai 7 (Tabel 5). Hal ini sesuai dengan Puspitasari, et al (2016) yang menyatakan bahwa pH permukaan air laut Indonesia bervariasi antara 6.0 - 8.5. Dengan demikian $\mathrm{pH}$ perairan ini tergolong normal dan cukup produktif serta ideal untuk kehidupan biota perairan. $\mathrm{pH}$ optimum bagi kehidupan karang yaitu berkisar antara 8.2 - 8.5 (Tomascik et al. 1997).

Salinitas pada tiap stasiun menunjukkan antara 31 sampai $32 \%$ (Tabel 5). Menurut Puspitasari (2016) kadar garam (salinitas) menunjukkan gram zat (material) terlarut dalam 1 kilogram air laut, dengan anggapan bahwa semua karbonat diubah menjadi Oksida, Bromida, dan Iodida diganti oleh Klorida dan semua bahan organik teroksidasi dengan sempurna. Nontji (1993) menambahkan tinggi rendahnya kadar salinitas ini tergantung oleh berbagai faktor antara lain: sirkulasi, penguapan, curah hujan, dan aliran sungai. Kisaran salinitas air laut adalah $>17 \%$, sedangkan di laut lepas berkisar antara $30-34 \%$.

\section{KESIMPULAN}

Kesimpulan yang didapat dari penelitian ini yaitu peta Sebaran Terumbu Karang di Pulau Kelapan Kabupaten Bangka Selatan berdasarkan Citra Satelit Sentinel$2 \mathrm{~A}$ yang memiliki 4 kelas yaitu terumbu karang, alga, pasir, dan alga bercampur pasir dengan klasifikasi terbimbing
(Supervised Classification), dengan proyeksi sistem koordinat WGS 1984 dan skala $1: 30.000$, luas terumbu karang yang terdapat pada Pulau Kelapan berdasarkan hasil pengolahan citra digital dengan klasifikasi diperkirakan seluas $16.5 \mathrm{Ha}$, dan kondisi secara umum terumbu karang di Pulau Kelapan pada stasiun 1 dan 2 masuk kategori sangat baik dengan persentase tutupan sebesar 75.54 dan $78.88 \%$, stasiun 3 kategori sedang dengan persentase sebesar $49.94 \%$, dan pada stasiun 4 termasuk kategori baik dengan persentase $63.74 \%$. Indeks Mortalitas (Tingkat kematian) berkisar antara $0.012-0.486$. Jumlah keragaman jenis genus yang ditemukan 19 genus.

\section{DAFTAR PUSTAKA}

Badan Pusat Statistik. 2017. Kabupaten Bangka Selatan Dalam Angka 2017. Katalog : $280 \mathrm{hlm}$.

Brando, V.E., Bresciani, M., Giardino, C., Hedley, J.D., Koetz, B., Kutser, T., Porte, J.L., Mumby, P.J. , Phinn, S.R. and Roelfsema, C.M. 2016. Preliminary Results From Sentinel 2 MSI Imagery For Coral Reef Mapping Applications. Australia: University of Queensland.

Damayanti, R., 2012. Pemetaan Terumbu Karang di Perairan Pulau Tabuhan Kabupaten Banyuwangi Menggunakan Citra Satelit Quickbird. Jurnal Kelautan: Indonesian Journal of Marine Science and Technology, 5(1):62-71

Dinas Kelautan dan Perikanan Provinsi Kepulauan Bangka Belitung. 2004. Profil Pulau-pulau Kecil di Kabupaten Bangka Tengah dan Kabupaten Bangka Selatan Provinsi Kepulauan Bangka Belitung. Bangka: Dinas Kelautan dan Perikanan.

Dwimasayanti, R. dan Kurnianto, D. 2018. Komunitas Makroalga di Perairan Tayando-Tam, Maluku Tenggara. Oseanologi dan Limnologi di Indonesia. 3(1):39-48 
English, S., Wilkinson, C. and Baker, V. 1994. Survey Manual For Tropical Marine Resources. ASEAN-Australia Marine Science Project: Living Coastal Resources. Australia Institute of Marine Science. Townsvile.

English, S., Wilkinson, C. and Baker, V.. 1997. Survey Manual for Tropical Marine Resources. Mc Graw Publication. Australia. 297p.

Guntara. 2015. Penajaman Citra dan Pemfilteran Spasial Dengan Er Mapper. Yogyakarta: Guntara Indonesia Corporation. $21 \mathrm{hlm}$.

Hartoko, A. 2010. Modul Praktikum MK. Aplikasi Inderaja \& SIG Perikanan. Semarang: Universitas Diponegoro.

Hartoko, A. 2012. Image Processing and Algorithm For Mangrove Using Quickbird. Marine Geomatic Center. Semarang : Jurnal of Management of Aquatic Resources, 2(1):19-27.

Helmi, M., Hartoko, A., Herkiki, S., Munasik dan Wouthuyzen, S. 2011. Analisis Respon Spektral dam Ekstraksi Nilai Spektral Terumbu Karang Pada Citra Digital Multispektral Satelit ALOSAVNIR di Perairan Gugus Pulau Pari, Kepulauan Seribu, Jakarta. Buletin Oseanografi Marina, 1(1):120-136

Keputusan Menteri Lingkungan Hidup. Nomor 04 Tahun 2001 tentang Kriteria Baku Kerusakan Terumbu Karang.

Lillesand, T.M. dan Kiefer, R.W. 1990. Penginderaan Jauh dan Interpretasi Citra. Dulbahri, Suharsono P, Suharyadi $H$, penerjemah; Sutanto, editor. Yogyakarta: Gadjah Mada University Press. Terjemahan dari: Remote Sensing and Image Interpretation. $725 \mathrm{hlm}$.

Luthfi, O.M. dan Anurah, P.T. 2017. Distribusi Karang Keras (Scleractinia) Sebagai Penyusun Utama Ekosistem Terumbu Karang di Gosong Karang Pakiman, Bawean. Depik. 6(1):9-22.

Malik, A. 2008. Pengolahan Citra Digital Dengan Er-Mapper Versi 7.0. Makassar: Universitas Negeri Makassar

Marsadin, W., Ulqodry, T.Z. dan Fauziyah. 2011. Studi Keterkaitan Komunitas Ikan Karang dengan Kondisi Karang Tipe Acropora di Perairan Sidodadi dan Pulau Tegal, Teluk Lampung Kab. Pesawaran, Provinsi Lampung. Maspari Journal. 3(1):42-50

Muzaki, F.K., Muhajir, F., Ariyanto, G. dan Rimayanti, R. 2010. Kondisi Terumbu Karang di Perairan Bangka, Provinsi
Bangka Belitung. Jakarta: Pusat Penelitian Oseanografi-LIPI.

Neviaty, P.Z. 2015. Kondisi Terumbu Karang dan Asosiasinya Dengan Bintang Laut (Linckia laevigata) di Perairan Pulau Tunda, Kabupaten Seram, Provinsi Banten. Jurnal Teknologi Perikanan dan Kelautan. 6(1):1-10.

Nontji. A. 1993. Laut Nusantara. Djambatan. Jakarta, $367 \mathrm{hlm}$.

Purbani, D., Kepel, T.L. dan Takwir, A. 2014. Kondisi Terumbu Karang di Pulau Weh Pasca Bencana Mega Tsunami. Jurnal Manusia dan Lingkungan, 21(3):331340.

Puspitasari, A.T.T., Amron, Alisyahbana, S. 2016. Struktur Komunitas Karang Berdasarkan Karakteristik Perairan di Taman Wisata Perairan (TWB) Kepulauan Anambas. Omni Akuatika, 12(1):55-72

Pusat Pemanfaatan Penginderaan Jauh. 2015. Pedoman Pengolahan Data Penginderaan Jauh Untuk Ekosistem Terumbu Karang. Jakarta: Lembaga Penerbangan dan Antariksa Nasional.

Prawoto, C.D. dan Hartono. 2016. Pemetaan Habitat Bentik dengan Citra Multispektral Sentinel-2A di Perairan Pulau Menjangan Kecil dan Menjangan Besar, kepulauan Karimun Jawa. Geografi Universitas Gadjah Mada: 8 $\mathrm{HIm}$.

Rizal, S., Pratomo, A. dan Irawan, H. 2016. Tingkat Tutupan Ekosistem Terumbu Karang di Perairan Pulau Terkulai. FKIP-UMRAH: $11 \mathrm{HIm}$.

Setiawan, F., Pardede, S.T., Tasidjawa, S. dan Noval, R. 2017. Status Ekosistem Terumbu Karang di Kabupaten Sitaro. Laporan Teknis: $61 \mathrm{HIm}$.

Siregar A., Utomo B. dan Harahap, A.H. 2017. Studi Tutupan Terumbu Karang di Perairan Pulau Unggeh Kecamatan Badiri Kabupaten Tapanuli Tengah Sumatera Utara. Sumatera Utara: Universitas Sumatera Utara.

Suharsono. 2008. Jenis-jenis Karang di Indonesia. Jakarta: Pusat Penelitian Oseanografi LIPI

Tomascik, T., Mah, A.J., Nontji, A. dan Moosa, M.K. 1997. The Ecology of The Indonesian Seas. Periplus Edition. Singapore.

Wibawa, I.G.A. dan Luthfi, O.M. 2017. Kualitas Air Pada Ekosistem Terumbu Karang di Selat Sempu, Sendang Biru, Malang. Jurnal Segara. 13(1):25-35. 
Winarso, G., Asriningrum, W., Suwargana, N., Parwati, E., Marini, Y., Anggraeni, N., Purwanto, A.D., Suherman, F.A., Supriyono, A., Putranto, H.E. dan Godoras, T. 2015. Litbang
Pemanfaatan Data Penginderaan Jauh Untuk Ekosistem Pesisir (Mangrove, Terumbu Karang). Jakarta: Pusat Pemanfaatan Penginderaan Jauh, LAPAN, $61 \mathrm{hlm}$. 